\title{
The Identification and Validity of Certain Species of Ascidians.
}

\author{
By \\ N. J. Berrill, B.Sc., \\ Department of Physiology, University of Leeds.
}

With 6 Figures in the Text.

\section{CONTENTS.}

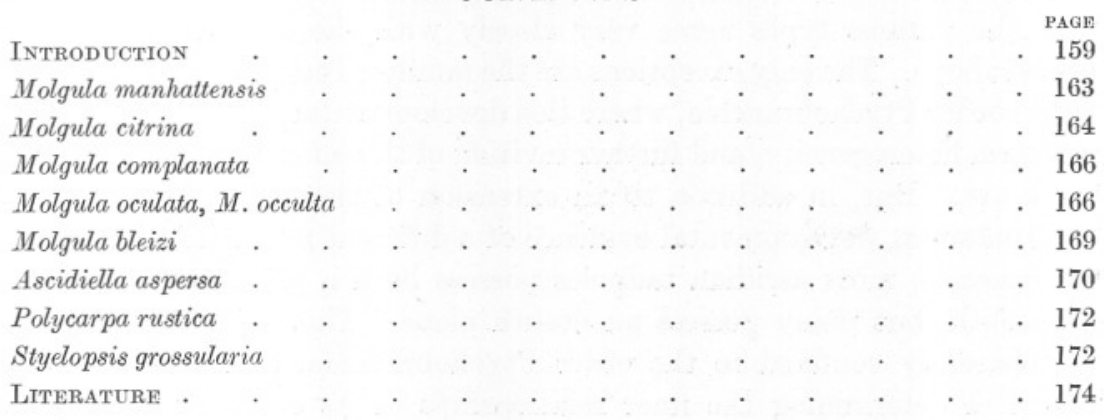

INTRODUCTION.

There has existed in the past, and still does exist, considerable confusion both in the question of a satisfactory basis for the classification of ascidians and that of the validity of many species.

The principal orders and families are fairly stereotyped, and confusion and divergent opinion is mainly confined to the internal classification of the various families. These differences have a twofold origin, in that classifications have been constructed by various authors on three distinct bases, and that it is very difficult to distinguish between structures which are similar through relationship and those which are similar through convergent or parallel development. Further difficulty arises from the fact that authors describing a new species with a view to fitting it into one particular classification, have often given insufficient details for its accurate inclusion in another scheme. There is also divergent opinion as to the correct nomenclature that should be employed, but with that this paper is not concerned.

Briefly, the bases used for classificatory purposes within the families have been the characters of the branchial sac, of the gonads, and, to a lesser degree, of development; that this last has not been used to the 
extent that it might be has been due primarily to the relative difficulty in making the necessary observations.

This paper deals mainly with the family Molgulidæ (Cæsiridæ), but first a few points may be made concerning the classification of the class Ascidiacea as a whole.

The class has been divided by Seeliger and Hartmeyer (1909) into three orders: Ptychobranchia, Dictyobranchia, and Krikobranchia, each consisting of four families. This system was constructed with reference to adult structures alone, and is one of a series of such. Whether it is a natural division will only be known when yet more is known of the adult anatomy and of the development and physiology of the group.

One confirmation has been made by Huntsman (1915), who worked out the mode of formation of the developing protostigmata and found that the various types agree very closely with the classification mentioned above. The only exceptions are the families Tethyidæ and Styelidæ of the order Ptychobranchia, where this developmental evidence indicates a certain heterogeneity, and further revision of these families may become necessary. But, in addition to an extension of the observations made by Huntsman, developmental evidence of a different nature can be used ; for example, most ascidian tadpoles possess both a pigmented eye and an otolith, but many possess an otolith alone. This type of variation is apparently confined to the order Ptychobranchia, and may become useful in determining the finer relationships of its component genera. Another variant in development is connected with the atrial syphon. This single syphon is usually and probably primitively formed by the independent invagination of a pair of atrial sacs, the openings of which later become involved in a single median dorsal invagination, but in many forms the invagination is median and single from the very beginning, though below the surface of the larva it bifurcates to form the two atrial sacs. Of the forms so far studied, all those belonging to the orders Dictyobranchia and Krikobranchia possess the first type of development, while those of the Ptychobranchia have the latter type; but the number of species investigated at present is insufficient to warrant an assertion that the fused type of development is universal in, and typical of, the Ptychobranchia. In any case, this variation in atrial development will be of use, either in confirming or correcting its subdivision. A table showing which species have at present been investigated is appended (p. 162).

The family Molgulidæ has been the subject of much discussion since 1870, when Lacaze-Duthiers first discovered that there were great differences in the development of its numerous species. Briefly, the species may be divided into two groups according to whether they possess a typical swimming larva with an otolith and fully formed tail, or whether 
these two structures have been eliminated from their development. This difference in development is very striking, and the results of a detailed investigation of it will be included in a later paper. LacazeDuthiers, however, considered that these larval differences were of more fundamental importance than adult anatomical differences and accordingly split the family into two genera, Molgula and Anurella, according to whether the larvæ possessed a tail or not. This scheme certainly brings together species which are ill-assorted from all other points of view, and has not been followed by other authors to any extent. That convergence has occurred to a considerable extent in connection with this modification of development will be shown in the paper mentioned above, and the types of development within this family do not afford a good basis for determining relationships. Hartmeyer (1909) and Van Name (1912) have used the details of the adult branchial sac as the chief diagnostic characters, while Huntsman (1922) considers that convergent parallel development may have occurred to a very great extent in that structure, and that the nature of the gonads and their related structures is much more indicative of relationship. But while it is considered that the one set of characters is as important as the other, it is not the purpose of this paper to discuss this question. Hartmeyer in his last work (1923-24), published posthumously, retains in the main his original point of view, but minimises the importance of many minor diagnostic characters and maintains that there are relatively few species of Molgulæ compared with those mentioned in his earlier account (1909) and that of Van Name (1912). In this connection he ignores developmental differences altogether, and many of his species described in 1923 contain forms whose development may be of either type. Even excluding developmental characters most of his enlarged species can be split into forms readily recognisable, especially in the living state, as other previously described species. Only in one case does the embryological evidence tend to confirm his grouping, and that is his inclusion of Molgula ampulloides under Molgula manhattensis.

The different characters that have been used in correcting or confirming his conclusions as to the synonymity of various species are of the organisation of the egg and the larval and post-larval development. Thus the egg can vary in size, and in the nature and number of its follicle cells and membranes. The tadpole stage may be completely eliminated, or if present the proportions and size of the tadpole may vary. The embryo may hatch through digestion of the egg membranes or through their rupture; while another set of diagnostic characters is to be found in the arrangement and number of the extensions of the bodywall, ampullæ, forming a temporary respiratory and fixatory organ for the metamorphosing larva. Only those of the species Hartmeyer has grouped under 
one specific name, the validity of which is being reaffirmed, will be discussed. For the complete lists of his supposedly synonymous species the reader is referred to the original paper (1923).

Table to show Characters of Ascidian Tadpoles

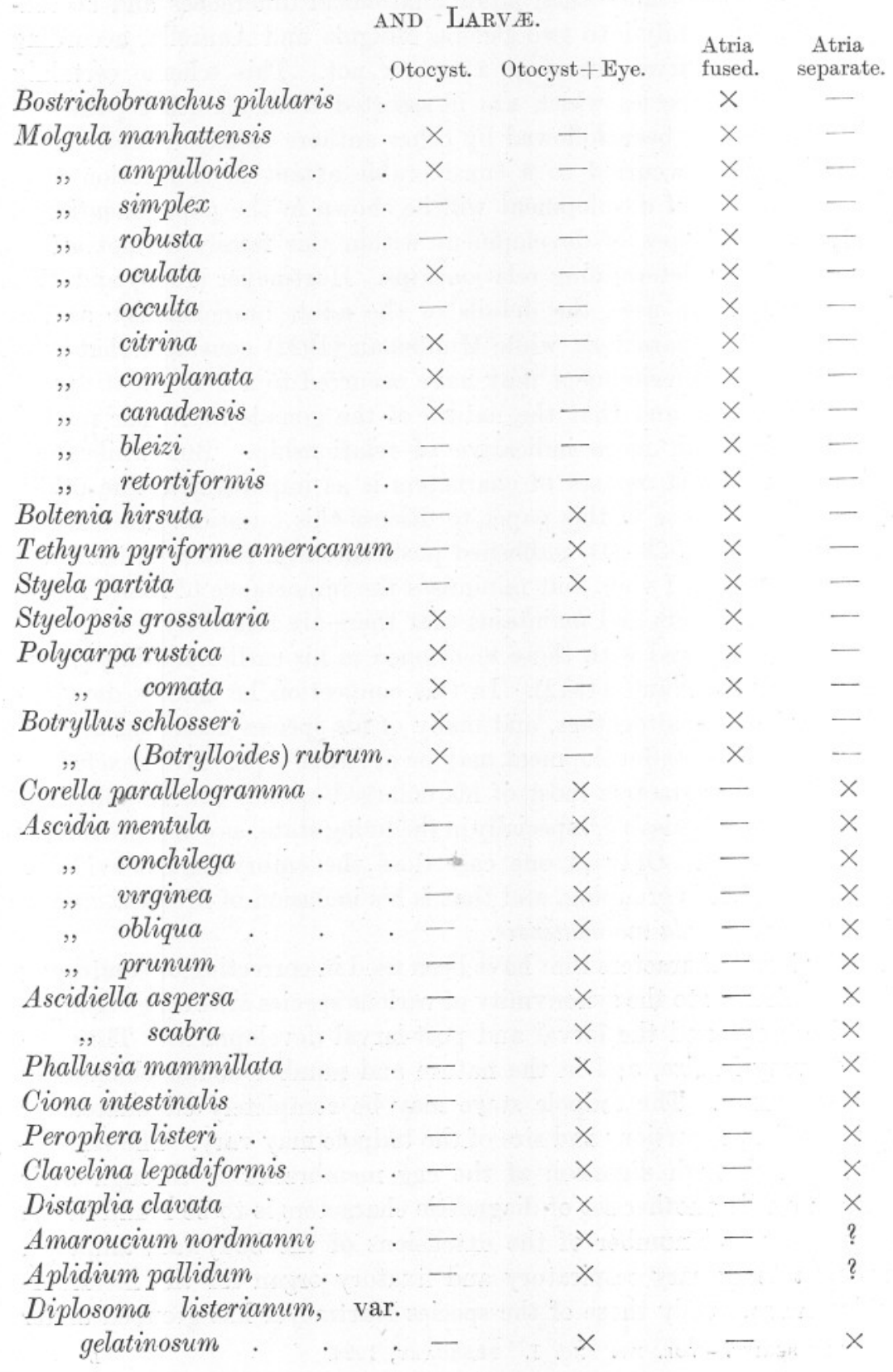


Molgula manhattensis de Kay.

According to Hartmeyer this species should include amongst others $M$. ampulloides van Beneden, $M$. socialis Ald., $M$. simplex Ald., $M$. macrosiphonica Kupfi., and $M$. papillosa (Huntsman). He also considered $M$. robusta van Name to be a variety of $M$. manhattensis, but A. M. Lucas (1927) has shown that $M$. robusta possesses an anural development while $M$. manhattensis produces typical tadpoles, and this difference in development merits at least a specific distinction.

Molgula ampulloides has a development similar in all respects to that of $M$. manhattensis. The eggs are of the same diameter, and have similar

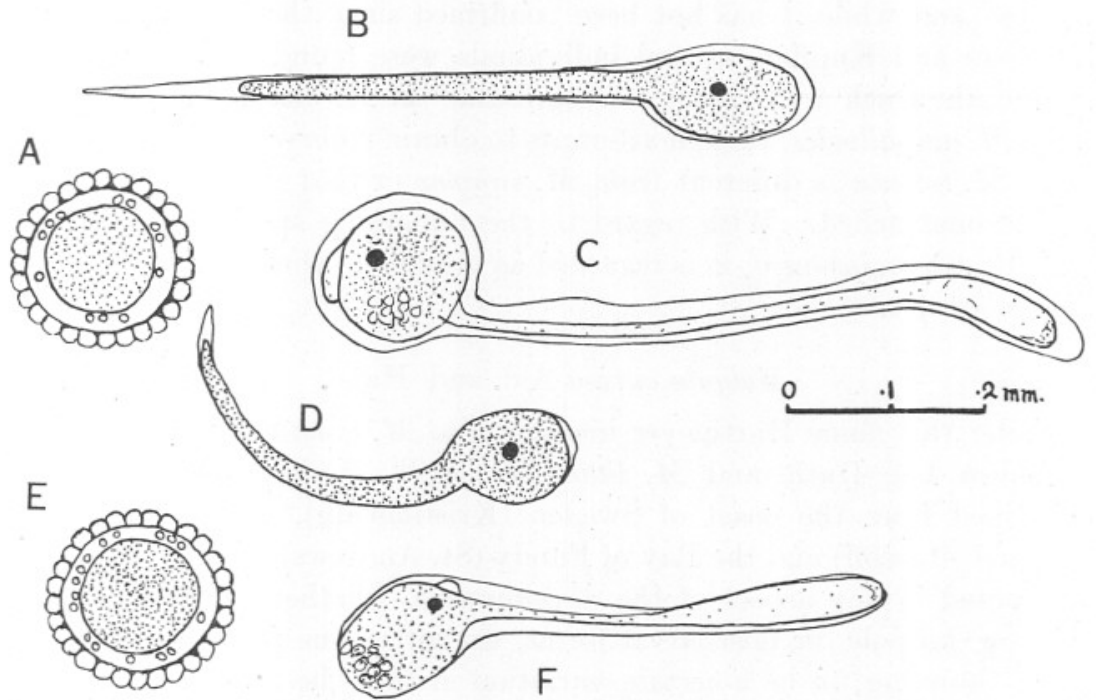

FrG. 1.-A, B, C, egg, tadpole, and metamorphosing tadpole with respiratory ampulla of Molgula manhattensis. E, D, F, do. Molgula ampulloides.

follicle cells and develop outside the parent. Both forms produce tadpoles with their characteristic otolith. Hatching is by digestion of the egg membrane, and in each case one long respiratory ampulla grows out four or five times the length of the body (see Fig. 1), while three or four shorter ampullæ develop later. Van Name (1912), after examining both forms, came to the conclusion they were not identical. Certainly the region of attachment and external appearance differ somewhat, but it is doubtful whether the differences are sufficiently great to justify the retention of M. ampulloides as a distinct species. But that the difference is such that a variety is justifiable is believed, and it is suggested that $M$. ampulloides be $M$. manhattensis $\mathrm{v}$. ampulloides.

It should be noted that both these forms occur only in very shallow 
water, and may be found in the intertidal zone. M. manhattensis was described from the American coast, while $M$. ampulloides was described from the European coast.

M. simplex is in a different category. It has been described both by Lacaze-Duthiers (1877) and by Kupffer (1872) as possessing anural development, and while the anatomical differences between the adults are small, they are quite definite and the ensemble produces a difference in appearance which is very obvious. Molgula simplex has been recorded only from depths below 15 fathoms, and compared with $M$. ampulloides is more spherical and has much shorter syphons. The difference in development is sufficient, however, to maintain $M$. simplex as a distinct species, and while it has not been confirmed since the time of LacazeDuthiers and Kupffer, several individuals were found in the region of Plymouth which were readily recognisable as $M$. simplex and distinct from $M$. ampulloides, though attempts to obtain embryos were unsuccessful. M. robusta is different from $M$. simplex in that it is asymmetrical and is unattached. With regard to the remaining species, M. socialis and $M$. macrosiphonica, it is regarded as unproven whether they be valid species or not.

\section{Molgula citrina Ald. and Hanc.}

Under this name Hartmeyer includes also M. nana Kupff., M. echinosiphonica Lac.-Duth. and M. littoralis Verrill. Individuals have been examined from the coast of Sweden (Kristineberg), from the English Channel (Roscoff) and the Bay of Fundy (St. Andrews), and no difference was noted in any aspect of the development, whether in the nature of the egg, tadpole, or post-larval forms, except in one particular. There seems, however, to be a certain variation in that the form described by Lacaze-Duthiers at Roscoff as $M$. echinosiphonica never attains the size reached by those in other regions, and in addition possesses well-developed test spines on the branchial syphon, spines which are developed hardly at all in the other forms.

The only variation that occurs in development is in connection with the hatching mechanism, and is of importance in that Caswell Grave (1926) has used it as a justification for maintaining the American Molgula citrina as a species distinct from the $M$. nana and $M$. echinosiphonica of European shores. All the forms are viviparous, and in every case the larva emerges by means of rupture of the egg membrane by the swelling larval test and respiratory ampullæ, and not by digestion of the membrane (see Fig. 2).

Grave describes the difference between the American and European forms as though it were a fundamental difference in development. Actually this difference is that while the tadpoles of the American form 
usually succeed in rupturing the egg membrane by the swelling of their anterior end, those of the European forms very often fail to do so at that stage, and rupture occurs later by the swelling larval test and outgrowing

A

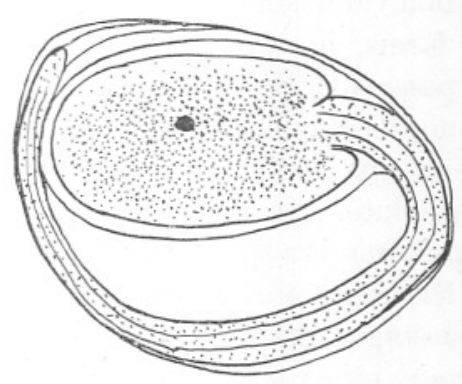

C

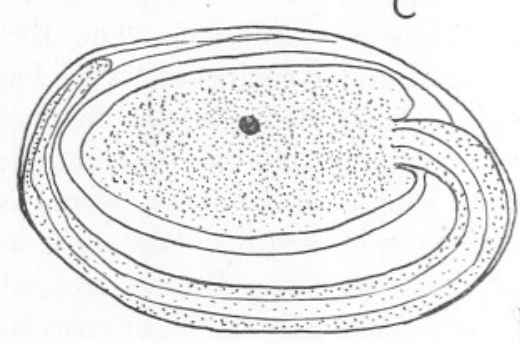

e

B
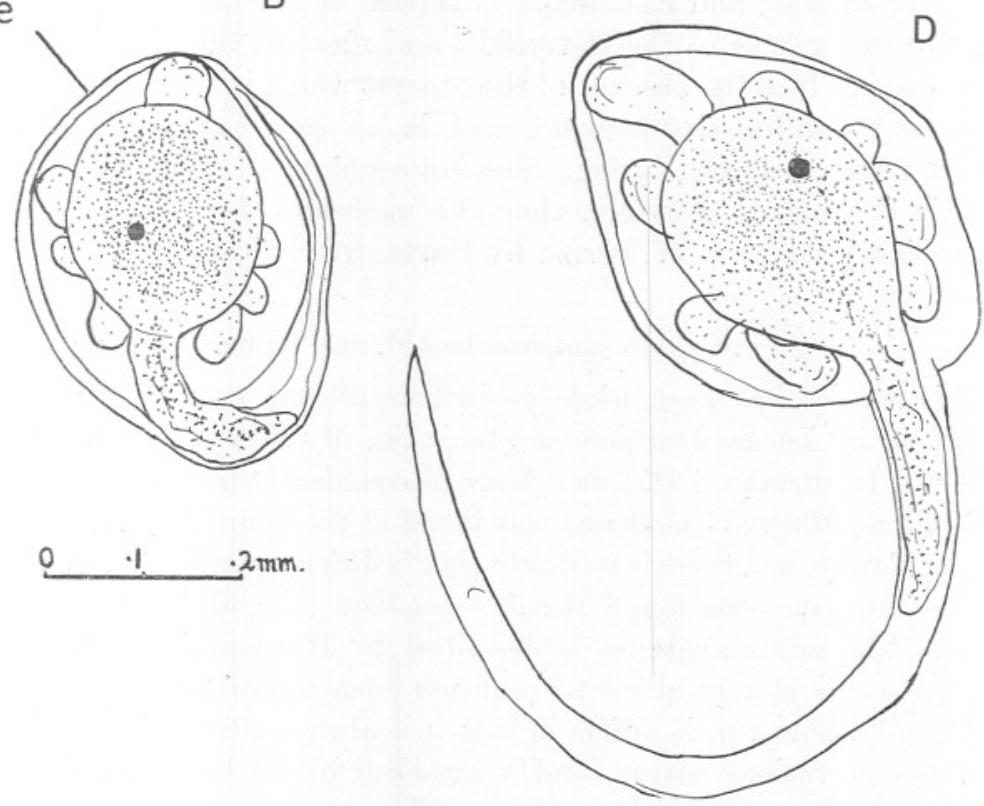

FIG. 2.-A, unhatched tadpole. B, same undergoing metamorphosis of Molgula nana. e, egg membrane. C, unhatched tadpole. D, hatched tadpole undergoing metamorphosis of Molgula citrina.

respiratory ampullæ, a stage where the tail has usually been absorbed. The swelling of the anterior part of the tadpole is of the same extent in both types, and all that is implied is that the egg membrane of the European forms on the average is tougher than that of the American form. Grave never found the second type of hatching among his material, and 
as:umed also that the first type does not occur in the European forms. This is not the case. Several hundred individuals of Molgula citrina, containing altogether many thousand larvæ, were examined at St. Andrews, and the occurrence of post-metamorphic hatching was found on the average to be $2-3$ per cent. Individual variation was considerable, as might be expected. The European forms, however, examined at Roscoff and Kristineberg were found to possess larvæ over 80 per cent of which hatched after the onset of metamorphosis, though by no means all did so, so that the difference between the method of hatching in the American and European forms is not absolute. In any case such a difference in the time of hatching would hardly merit a specific distinction, as Grave suggests $\mathrm{He}$ also suggests that the absence of a larval eye and the presence only of the otocyst is the first stage towards the acquisition of the anural development found in certain other species of Molgula. Obviously this is not the case, for there is no direct evidence that an eye was ever present, and its absence is typical of the family Molgulidæ as a whole, as well as of the Botryllidæ and most of the Styelidæ, of the same order. It is the absence of the otocyst which is correlated with the presence of anural development, and in no case has this been found absent where such development does not occur.

It is concluded, therefore, that the inclusion of Molgula nana and M. echinosiphonica in M. citrina by Hartmeyer is justifiable.

\section{Molgula complanata Ald. and Hanc.}

This species has been made to include all the species of the genus described by Lacaze-Duthiers as Ctenicella, Molgula papillosa of Verrill (but not Huntsman, 1912) and Molgula canadensis Huntsman.

Of these, Molgula canadensis was found at the mouth of l'Etang River, Bay of Fundy, and there is no doubt that it differs from the $M$. complanata of the European coast and the $M$. papillosa (Verrill) of the American coast. The adult anatomy is described by Huntsman, 1912, and the species seems closely allied to, but not identical with, the other two. Externally, however, it differs in that it is always covered with adherent particles of various nature, and is attached by its base and not by its side, while the eggs and larvæ have different proportions from those of M. complanata (see Fig. 3).

How far Hartmeyer is justified in the case of his other inclusions it is difficult to say.

\section{Molgula oculata Forbes.}

Under the name Molgula oculata are now included M. occulta (Kupfi.), M. roscovita (Lac.-Duth.), M. bleizi (Lac.-Duth.), and M. solenata (Lac.Duth.). Four of these were described by Lacaze-Duthiers (1874-1877), 
while $M$. occulta was described by Kupffer (1875). It is believed that $M$. occulta and $M$. roscovita are synonymous forms, and that in all probability they will be found to be identical with the Molgula described by Alder (1863) and Forbes (1848), and figured in Ald. and Hanc., 1907, under the name Ascidia chonchilega, and, if so, the name will have to be $M$. chonchilega Alder, but this cannot be determined until the type specimen is found. Thus under the single specific name "oculata" Hartmeyer will be shown to have included at least three valid species including $M$. oculata itself, and a probable fourth. It must be admitted

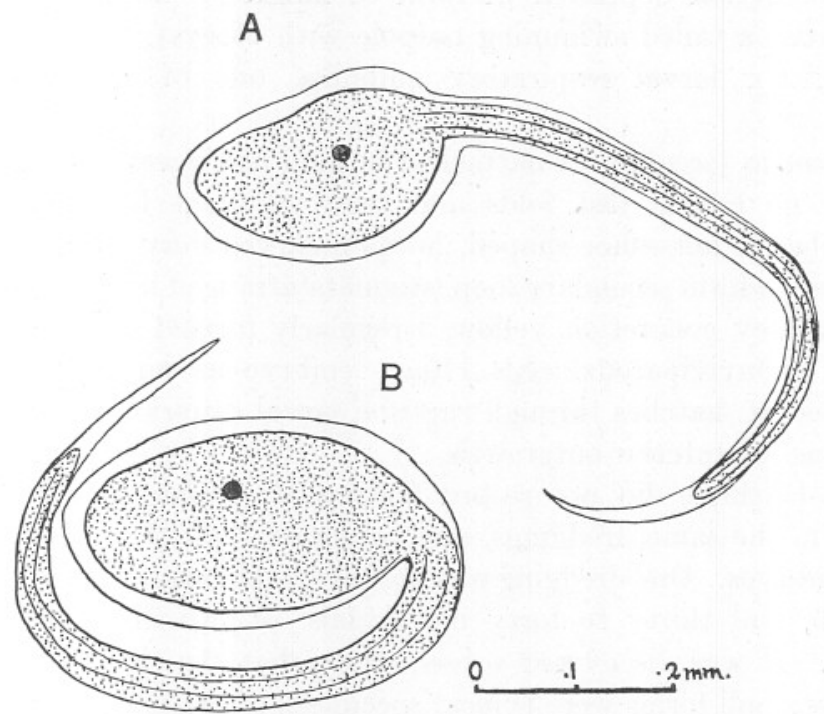

Fig. 3.-A, tadpole of Molgula complanata.

B, tadpole of Molgula canadensis.

in this case that the character of development of all these forms was thought to be anural at the time his account was written, though one anural species, $M$. simplex, he included elsewhere. The mistake was made in the first place by Lacaze-Duthiers himself in his original description of Molgula oculata, where he stated that development was direct, and that tailed tadpoles were not formed.

In 1874 he described two species of Anurella (Molgula) from Roscoff, which were very similar in external appearance. The commonest to which he gave the name "roscovita" was found in large masses free in the sand at low water of high spring tides in the region of the Roche de Loup, and may still be found there in extraordinarily large numbers. The other he identified as the "oculata" of Forbes, and was and still may be found in dredgings from deeper water near the St. Pol River. 
For detailed descriptions the reader is referred to the original paper, but as Hartmeyer considers them identical forms a brief account of their differences and resemblances is given here. A comparison of their development is given as well.

Molgula oculata. Unattached in sand and covered with adherent particles, test between syphons free from sand, syphons protected by lateral folds of test; dorsal tubercle horseshoe-shaped with horns very much incurved, gut loop not curved to form secondary loop, stigmata irregular, and spiral arrangement inconspicuous, kidney almost filled by purple concretion deposited in form of lamellæ; nonviviparous, eggs $110 \mu$; larva a tailed swimming tadpole with otocyst, hatching through digestion, six larval respiratory ampullæ, one of which is always anterior.

$M$. roscovita (occulta). Unattached in sand and covered with adherent particles, no lateral test folds and sand adherent between syphons; dorsal tubercle horseshoe-shaped, horns incurved very slightly, gut loop not curved to form secondary loop, stigmata arranged in very conspicuous spirals, kidney concretion yellow, irregularly formed and by no means fills sac; nonviviparous, eggs $110 \mu$; embryo at no time develops a tail or otocyst, hatches through rupture, larval respiratory ampullæ five, there being no anterior outgrowth.

Lacaze-Duthiers did not record finding $M$. oculata and $M$. roscovita together in the same dredgings, and he stated that $M$. oculata possessed anural embryos. One dredging was made from the same region in September, 1926, and thirty to forty individuals, of two distinct sizes, were included. It was discovered subsequently that the three large $(5 \mathrm{cms}$.) and a few small forms were typical specimens of $M$. oculata, but that the remainder $(3 \mathrm{cms}$.) were identical with $M$. roscovita in every respect. In the contracted state, however, apart from size, no external difference could be seen between them, and it is suggested that when Lacaze-Duthiers obtained his material from this region he examined the anatomy of the larger specimens and obtained his cultures from the smaller ones, without being aware that he had the two species present. In any case, whatever its origin, there seems to be no doubt that a mistake was made, for cultures made from all the individuals of $M$. oculata gave rise to typical urodele larvæ, while the others all produced anural larvæ, which differed in no detail from those of the shore-living $M$. roscovita.

A preserved collection from one dredging has since been found at the Marine Biological Laboratory at Plymouth, and there also were found the same two species of Molgula in close association, large individuals, up to $8 \mathrm{cms}$, only of $M$. oculata, and small individuals of both species. One to two hundred individuals were dredged near Kristineberg in 20 fathoms in the Koljö Fjord in 1926, which afterwards were determined to be 
identical with the species described as $M$. roscovita by Lacaze-Duthiers, though attempts at rearing larvæ were all unsuccessful.

In 1875 Kupffer described a species from the North Sea which he named. $M$. occulta, and from his description this seems to be undoubtedly identical with $M$. roscovita rather than $M$. oculata, and while Lacaze-Duthiers had already published his account of the species, he did not name it until two years after Kupffer's publication, so that until it is shown that the
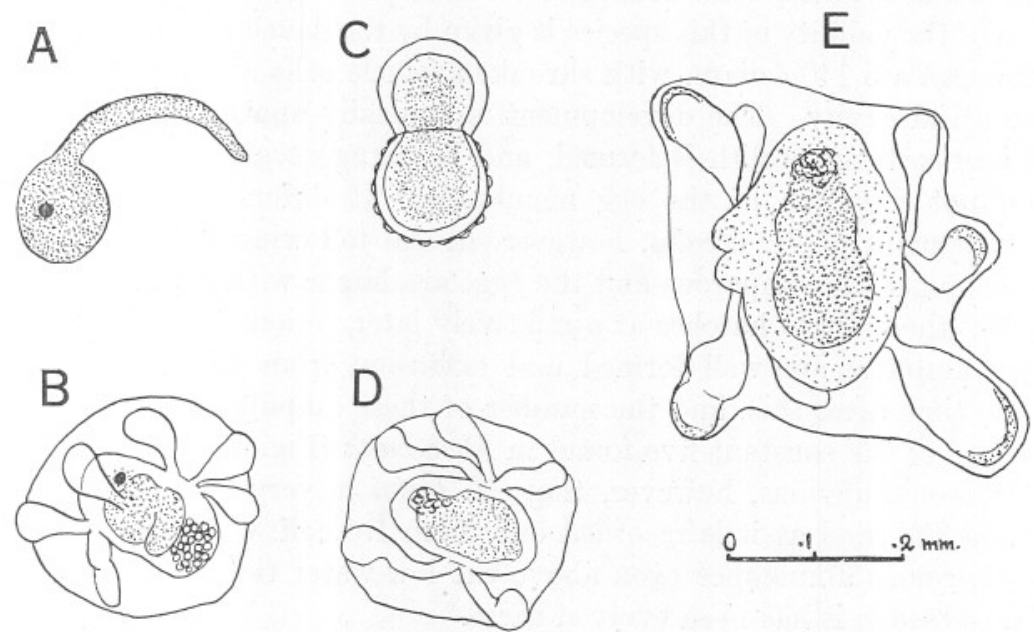

Fig. 4.-A, tadpole. B, metamorphosed larva of Molgula oculata. C, embryo hatching. D, equivalent stage to (B) of Molgula occulta. E, do. Molgula bleizi.

M. conchilega of Forbes and Alder is a synonymous species it must be known as Molgula occulta Kupfif.

Lacaze-Duthiers described another anural species under the name Anurella solenata, which Hartmeyer includes as $M$. oculata. If this prove not to be a valid species, as it may well be, it will be synonymous not with $M$. oculata, but with $M$. occulta.

\section{Molgula bleizi Lac.-Duth.}

The other species listed by Hartmeyer under the name $M$. oculata is M. bleizi, described by Lacaze-Duthiers, 1877. This form was said by him to possess anural development, which fact has been confirmed by myself and by Damas, 1902, and has not yet been discovered elsewhere than at Roscoff. It is a small form of average size, $5 \mathrm{~mm}$., and was found attached side by side with Molgula echinosiphonica (citrina) on Styelopsis (Dendrodoa) grossularia in grottoes of the Roche de Loup and elsewhere. 
The adult anatomy is well described by Lacaze-Duthiers, and it will be seen that the anatomical differences between this form and $M$. oculata. and $M$. occulta are relatively small. Principally one must note, apart from the fixed habitat and great reduction in size, the smooth translucent test: it has a conspicuous spiral arrangement of the stigmata to form infundibula, as in $M$. occulta, and it differs from both $M$. oculata and $M$. occulta in that in these forms the vas deferens does not accompany the ovary and oviduct, while in $M$. bleiz $i$ it does. The most complete vindication of the validity of this species is given by the developmental evidence. The eggs are $140 \mu$ diam. with shrunken follicle cells and develop within the atrial cavity. The development is typically anural in that no tail of any sort nor otolith is formed, and hatching occurs through rupture and not digestion of the egg membrane. It differs from the anural development of $M$. occulta, however, in the following particulars: the development is viviparous and the eggs are larger with shrunken follicle cells ; the embryo hatches at a relatively later period, when the respiratory ampullæ are well formed and extrusion from the parent occurs some time after this, and the number of these ampullæ is seven to nine instead of the constant five found in $M$. occulta (Fig. 4).

It seems obvious, however, that $M$. bleizi is very closely related to $M$. occulta, and as it is recorded only from Roscoff, where $M$. occulta is in enormous abundance even above the low-water tide level, it is more than possible it has been evolved there.

Of the relationship existing between $M$. occulta and $M$. oculata less can be said ; it is significant, however, that their distribution is coextensive, and is confined to North European waters and to the northern parts of Mediterranean waters. The significance of the difference in development will be discussed elsewhere.

\section{Ascidiella aspersa Müll.}

O. F. Müller, 1776, described from the Christiania fjord two species which he named Ascidiella aspersa and Ascidiella scabra respectively. Hartmeyer (1923) now considers them to be identical and retains the first name. This is considered to be unjustifiable as the two species, especially in the living condition, can be easily distinguished. In general structure there is very little difference, but in appearance and in some other respects they differ very markedly. Ascidiella aspersa is attached to the substratum by its posterior or basal end and can attain a length of 12-13 cms., while Ascidiella scabra is attached by its side and never attains a length of more than $4 \mathrm{cms}$. The atrial syphon of $A$. scabra is relatively nearer the anterior branchial syphon than is the case in $A$. aspersa. Internally, the renal vesicles are much less extensively distributed, and the red pigment is spread usually over most of the mantle 
in A. scabra, while in A. aspersa it is usually more localised near the syphons. Correlated with the difference in maximum size is a difference in the size at which the two species mature. Ascidiella aspersa is rarely mature until it exceeds $5 \mathrm{cms}$. in length, while Ascidiella scabra is mature when it reaches a length of $2 \mathrm{cms}$. Finally, there are very marked differences in the organisation of the living egg. This is shown most conspicuously when the eggs have lain in sea-water for an hour or two. $A$. aspersa possesses an incomplete investment of inner follicle or testa cells, and an outer investment of follicle cells of about $20 \mu$ diameter. A. scabra has a complete investment of inner follicle cells and an outer investment of cells of the same size, i.e. $10 \mu$ diameter; further, the chorion on which

A

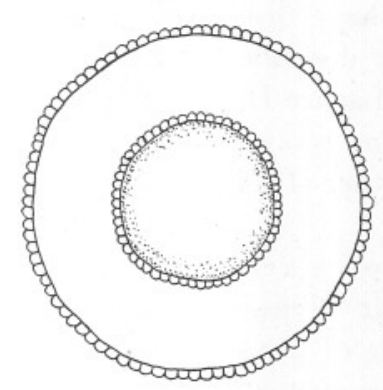

B

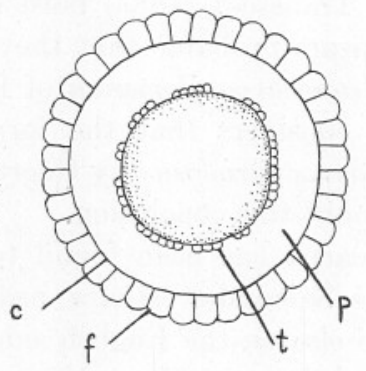

C

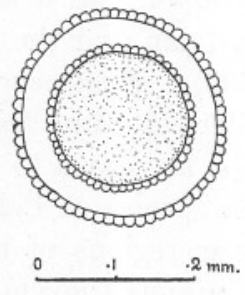

FIG. 5.-A, egg of Ascidiella scabra. B, of Ascidiella aspersa. C, of the small species of Ascidiella of Scandinavian waters. c, chorion. f, outer follicle cell. t. inner follicle cell. $p$, perivitelline jelly.

the outer cells rest is lifted from the ovum surface to a much greater extent than is the case in $A$. aspersa. Finally, the egg of $A$. aspersa floats in sea-water of salinity 30 to $35 \%$, and as far as is known is unique among Ascidian eggs in doing so (see Fig. 5).

Both species are apparently confined to European waters, from the Norwegian Sea to the eastern Mediterranean. Hartmeyer, in his account of the distribution, does not distinguish between the two forms. They occur together abundantly in the coastal waters of S.W. England, but while the smaller A. scabra is abundant at Roscoff and Skagerak, the only individuals found of A. aspersa were three brought in at Kristineberg in 1926. But their range of distribution seems to be much the same, and in one district at least they occur side by side, so that their differences cannot be correlated with different environments. It has yet to be shown conclusively that the abundant small species of Ascidiella of the Swedish coast is absolutely identical with $A$. scabra. This form certainly difiers in that it possesses a deep diffusely spread brown pigment, and has eggs 
which are semi-opaque instead of being translucent, and have a less extensive perivitelline space (see Fig. 5, C).

\section{Polycarpa rustica Lac.-Duth. and Del.}

This species is not mentioned by Hartmeyer (1923). There is some confusion in that Herdman (1893) described a species from the Isle of Man, first under the mistaken impression that it was Styela rustica, and later as Polycarpa glomerata. When the monograph of Lacaze-Duthiers and Delage was published, Herdman suggested that the species there described as Polycarpa rustica was identical with his species glomerata, but this does not seem to be the case. Polycarpa glomerata, according to Herdman, is an aggregate form with a branchial sac possessing but three folds, while Polycarpa rustica is solitary and has a branchial sac with four folds.

Heller (1877) and Traustedt (1883) both have described a Polycarpa glomerata, and it appears probable that they describe the same form as Herdman and the Heterocarpa glomerata of Lacaze-Duthiers and Delage (1892); Hartmeyer considers that the form was originally described under the name Distomus variolosus by Gaertner (1774), and there seems to be no reason to doubt this conclusion.

A species of Polycarpa has been found to be very abundant in the upper regions of the Salcombe estuary near Plymouth, but has been encountered nowhere else on the English side of the Channel, though it occurs fairly commonly on the West Mersea oyster beds, according to information supplied by Dr. Orton. This form was thought at first to be identical with the Polycarpa glomerata of Herdman, but structurally it agrees perfectly with the Polycarpa rustica of Lacaze-Duthiers, and will therefore be recorded here as such for the English coast for the first time. It may be noted here that Distomus variolosus has since been shown to possess the faculty of budding (de Selys Longchamps, 1917), and also to possess eggs the diameter of which is in the region of $.5 \mathrm{~mm}$., while Polycarpa rustica does not bud and has eggs of only $\cdot 15 \mathrm{~mm}$. diameter. Both specimens are viviparous, but the embryos of $P$. rustica are very much more numerous.

\section{Styelopsis grossularia Bened.}

This species is practically cosmopolitan, at least in the northern hemisphere, and ranges from the intertidal regions to below 200 fathoms, and therefore forms a good example of the extent to which the larval and postlarval characters discussed earlier in this paper may be influenced by normal changes in environmental factors.

Individuals from the intertidal regions of Plymouth and Roscoff in the English Channel have been examined, and these typically live in water of salinity $35^{\circ} \%$, temperature range $7-20^{\circ} \mathrm{C}$., and periodical 
exposure to air. Others were examined at St. Andrews, Bay of Fundy. These live in water of salinity $31 \%$, temperature range $0-10^{\circ} \mathrm{C}$., and occur mainly below the low-water mark.

In all these forms no difference was noted in the size or colour of the

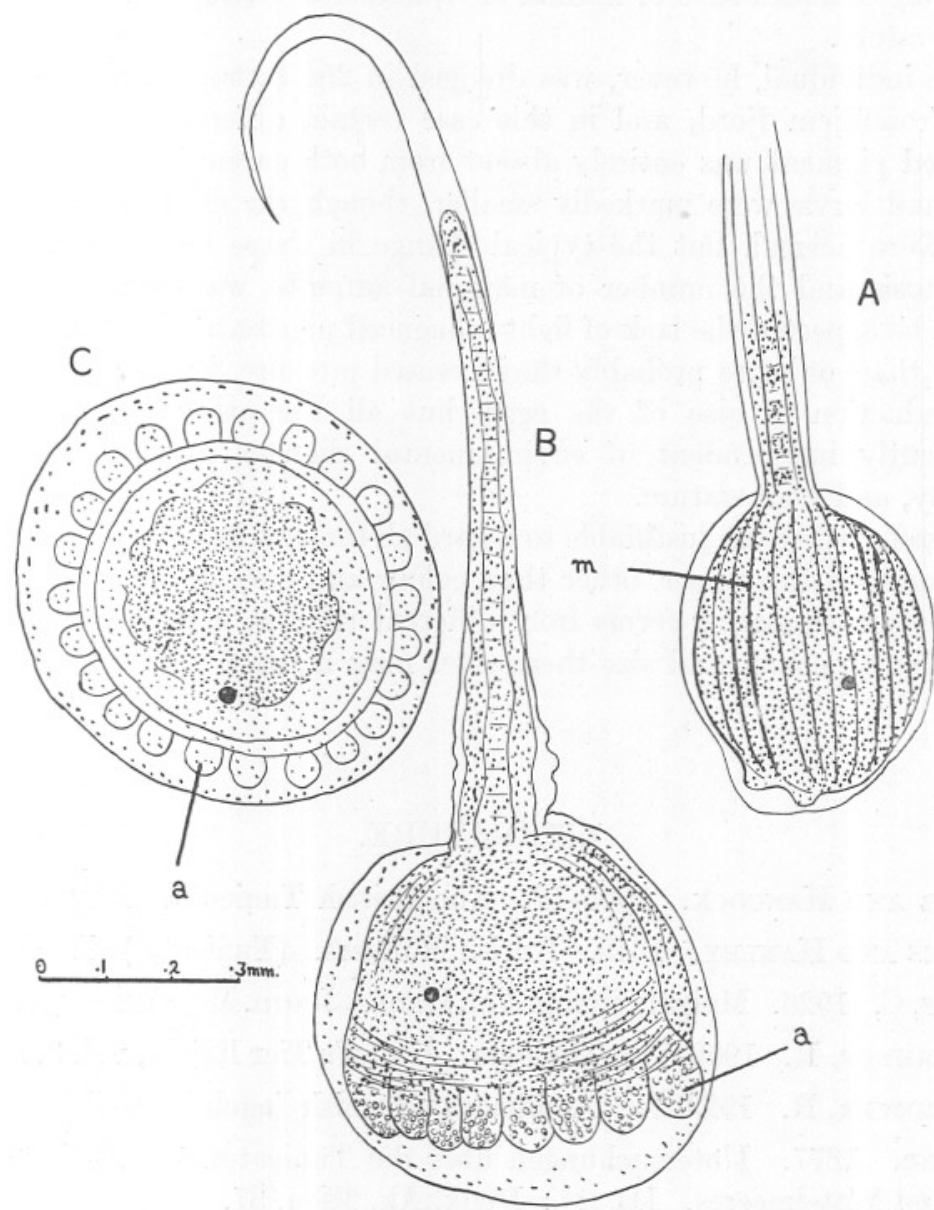

FIG. 6.-A, tadpole of Styelopsis grossularia. B, C, same undergoing metamorphosis. a, ampulla. $\mathrm{m}$, muscle band.

eggs, tadpoles, proportions of the tadpoles, nor in the nature of metamorphosis nor number of post-larval respiratory ampullæ.

The adults and larvæ are all diffused with a deep red pigment, but when metamorphosis ensues, muscles in the trunk of the tadpole contract, and by the time the tail has been absorbed the trunk is transformed from an ovoid shape to a medusoid shape, while the colour changes 
to a yellow-orange. At the same time twenty-three to twenty-five respiratory ampullæ grow out to form a ring round the anterior end, i.e. round the margin of the medusoid body (see Fig. 6).

In the forms mentioned above all these characters were constant, implying independence of normal environmental changes in salinity and temperature.

One individual, however, was dredged in 250 fathoms at Galgenes in the Trondhjem fjord, and in this case certain differences were noted. The red pigment was entirely absent from both parent and larvæ. The eggs and larvæ were markedly smaller, though the chorion and follicle cells were normal, but the typical change in shape occurred at metamorphosis and the number of marginal ampullæ was 24 ; so that as might be expected the lack of light influenced pigmentation, and possibly either that, or more probably the increased pressure, was responsible for the reduction in size of the eggs, but all the other characters are apparently independent of environmental changes in light, pressure, salinity, and temperature.

Therefore it seems justifiable to regard all the developmental characters mentioned in this paper, other than colour and size, of diagnostic value even when comparing forms from different regions, and when from the same region colour and size themselves may be used with caution.

\section{LITERATURE.}

Alder and Hancock. 1905-12. The British Tunicata. Ray Society. Forbes and Hanley. 1848. British Molluses. (Tunicata.) London.

Grave, C. 1926. Molgula citrina Ald. Hanc. Journ. Morphology, vol. 45. Hartmeyer, R. 1909-11. Tunicata. Bronn's Tier Reich., vol. 3, suppl. Hartmeyer, R. 1923-24. Ascidiacea. Danish Ingolf Expedition.

Heller. 1877. Untersuchungen über die Tunicaten des Adriatischen und Mittelmeeres. III (1): Denk. Ak. Mien. 37.

Huitfeld-KaAs, H. 1889. Synascidæ. Norske Nordhavs. Exped., vol. 7 .

Huntsman, A. G. 1912. Ascidians from the coast of Canada. Trans. Inst. Canad., vol. 9.

Huntsman, A. G. 1915. The development of protostigmata in Ascidians. Proc. Roy. Soc., vol. 86, B.

Huntsman, A. G. 1922. The Ascidian family Molgulidæ. Roy. Soc. Canada, vol. 16. 
KupfFer, C. 1872. Zur entwickelung der einfachen Asciden. Arch. mikr. Anat., vol. 8.

Kupffer, C. 1875. Tunicata. Ber. Komm. D. Meere, vol. 2. Berlin.

Lacaze-Duthiers, H. de. 1874. Les ascidies simples des côtes de France. Arch. Zool. expt. ser. I, vol. 3.

Lacaze-Duthiers, H. de. 1877. Pt. 2. Ibid., vol. 6.

Lacaze-Duthiers and Delage, Y. 1892. Faune de Cynthiadées. Mem. pres. Ac. France, vol. 45.

Lahille. 1890. Recherches Tunicates. Toulouse.

Lucas, A. M. 1927. The validity of Molgula robusta Van Name as a species distinct from $M$. manhattensis de Kay. Occ. papers Bost. Nat. Hist. Soc., vol. 5.

Müller, O. F. 1776. Zoologica Danica Prodromus. Havniæ.

Selys-Longchamps, M. DE. 1917. Sur le bourgeonnement des Polystyelines Stolonica et Heterocarpa. Bull. Sci. Fran. Belg., vol. 50.

VAN Name, W. G. 1912. Simple ascidians of the coast of New England. Proc. Bost. Soc. Nat. Hist., vol. 34 . 
